\title{
Effects of Stunting on Child Development: A Meta-Analysis
}

\author{
Milatur Rosyidah'), Yulia Lanti Retno Dewi²), Isna Qadrijati²) \\ 1)Masters Program in Public Health, Universitas Sebelas Maret \\ ${ }^{2)}$ Faculty of Medicine, Universitas Sebelas Maret
}

\section{ABSTRACT}

Background: Stunting is a condition where children under five have a low height for their age. Stunted children under five have a nutritional deficiency (malnutrition), thus affecting the maturity of nerve cells. In addition, they are susceptible to developmental delays such as slow motor movements, lack of intelligence, and slow social response. This study aimed to analyze the effect of stunting on child development based on the results of previous studies.

Subjects and Method: This study was a systematic review and a meta-analysis. The articles were searched systematically and comprehensively through several databases including Pubmed, Science Direct, and Google Scholar published from 2010 to 2020. It aimed to ensure the relevance of current findings in the health context and the possibilities for what would happen ahead. Eligibility criteria were used to select studies included in a systematic review/a metaanalysis. The researcher provided eligibility criteria using the PICO model. The population of this study was children. The intervention was stunting. The comparison was non-stunting. The outcome was child development. The article search was carried out for 2 weeks. The keywords were "Association between stunting and delayed development regression", "the effect of stunting on development", "the relationship of stunting to development", "stunting and development", "stunted and development". The articles were collected using PRISMA flow diagrams. The data were analyzed using Review Manager (RevMan) 5 software.

Results: This study reviewed 5 articles. The results showed that stunting increased the risk of abnormal development in children $(\mathrm{aOR}=3.71$; $95 \% \mathrm{CI}=2.35$ to $5.86 ; \mathrm{p}=0.760$ ).

Conclusion: Stunting increases the risk of abnormal development in children.

Keywords: stunting, development, child development

\section{Correspondence:}

Milatur Rosyidah. Masters Program in Public Health, Universitas Sebelas Maret. Jl. Ir. Sutami 36A, Surakarta 57126, Central Java. Email: milatur387@gmail.com. HP: 089620575849.

Cite this as:

Rosyidah M, Dewi YLR, Qadrijati I (2021). Effects of Stunting on Child Development: A Meta-Analysis. J Matern Child Health. 06(01): 25-34. https://doi.org/10.26911/thejmch.2021.06.01.03. (c) (i) (2) Journal of Maternal and Child Health is licensed under a Creative Commons

\section{BACKGROUND}

Children under five years of age, which is often abbreviated as "balita" are children who have reached the age of one year, or more popularly known as children under five (Ministry of Health, 2015). In the first five years, there is a time where children are very sensitive to the environment, walk quickly, and can never repeat it, thus calling the Golden Age. Development and growth at this time need serious attention. Children under five will be more open to the learning process but also very sensitive to the environment, both supportive and unsupportive (Amir et al., 2019).

According to BPS (Central Bureau of Statistics), the children-under-five mortality rate in 2012 was 34/1000 births (Basic Health Research). In 2017, the Infant Mortality Rate (IMR) was 111/1,00o live births (Banyuwangi Health Office, 2019). In 2018, the IMR was 138 people. This rate increased 
from the previous year (Banyuwangi Regency Government, 2019).

Stunting problems in developing countries such as Indonesia will be a public health problem that must be handled seriously and continuously. Based on the stunting prevalence data for children under five collected by the World Health Organization (WHO), Indonesia was the third country with the highest prevalence in the South-East Asia Region (SEAR). The average prevalence of stunting in children under five in Indonesia in $2005-2017$ was $36.4 \%$. Based on the results of Basic Health Research Data (Riskesdas) in 2018, the prevalence of stunting in children under five reached $30.8 \%$. It showed that 1 of 3 children under five was stunted. This rate did not meet the WHO standard: the maximum limit of children under five who were stunted by $20 \%$, which means that one-fifth of the total children under five were stunted. The number of children under five who were stunted in Indonesia was quite high compared to the prevalence in other developing countries such as Africa $18.6 \%$ 12, Ethiopia $26.4 \%$, Nigeria (22.2\%), Malaysia 20\%, and Thailand 10.5\% (Ministry of Health RI, 2018).

Stunting is a condition where children under five have a low height for their age. This condition is measured by a length or height that is more than minus two standard deviations from the WHO median growth standard for children. Stunting in children under five is a chronic nutritional problem caused by many factors such as socioeconomic conditions, maternal nutrition during pregnancy, illness in infants, and lack of nutritional intake in infants. Stunting in children under five ahead will have difficulties in reaching optimal physical and cognitive development (Ministry of Health RI, 2018). Stunted children under five have an insufficient nutritional intake, thus affecting the maturity of nerve cells. In addition, they are susceptible to developmental delays such as slow motor movements, lack of intelligence, and slow social response (Nurmalasari et al., 2019).

During the last few years, study on stunting with progress has been carried out throughout the world, including in Indonesia. Furthermore, in Indonesia, no one has conducted a systematic review with a meta-analysis on the effect of stunting on child development. Based on the description above, the authors were interested in conducting a systematic review and a meta-analysis to determine the effect of stunting on child development because there were only several studies conducted related to this study. This study result was expected to help determine the policies that should be carried out regarding stunting and the development of children under five. Therefore, this study aimed to analyze the effect of stunting on child development.

\section{SUBJECTS AND METHOD \\ 1. Study Design}

This study was a systematic review and a meta-analysis. The articles were searched systematically and comprehensively through several databases including: Pubmed, Science Direct, and Google Scholar published in 2010 to 2020. The article search was carried out for 2 weeks. The keywords were "Association between stunting and delayed development regression", "the effect of stunting on development", "the relationship of stunting to development", "stunting and development", "stunted and development".

\section{Populationand Sample}

Eligibility criteria were used to select studies included in a systematic review/a meta-analysis. The researcher provided eligibility criteria using the PICO model. The population of this study was children. The intervention was stunting. The comparison was 
non-stunting. The outcome was child development.

\section{Inclusion Criteria}

The included criteria were full-text articles with a cross-sectional design. The study subjects were children under five with stunting. The articles were published in English and Indonesian language. The control group was non-stunted children.

\section{Exclusion Criteria}

This study was conducted in a cohort, a casecontrol. The children had congenital diseases. The statistical results reported were not aOR.

5. OperationalDefinition of Variables Stunting was a growth and development disorder where children under five have a low length or height for their age (L/A or H/A) by looking at the $\mathrm{z}$ score. Development was an increase in the ability of children under five aged 12-60 months by looking at gross mo- tor, fine motor skills, language, and social by looking at the rate of their development results.

\section{Data Analysis}

The data processing was carried out using the Review Manager (RevMan 5.3) by calculating the effect size and heterogeneity to determine the study mode that was combined and formed the final meta-analysis result.

\section{RESULTS}

The article search through the database by journals is in Figure 1. Figure 2 shows the areas where articles met the inclusion criteria. The articles were in several regions in Indonesia such as Sleman Yogyakarta, Cirebon City, West Java, Indragiri Hilir Riau Regency, Karanganyar Regency, Central Java, and Bekasi City, West Java.

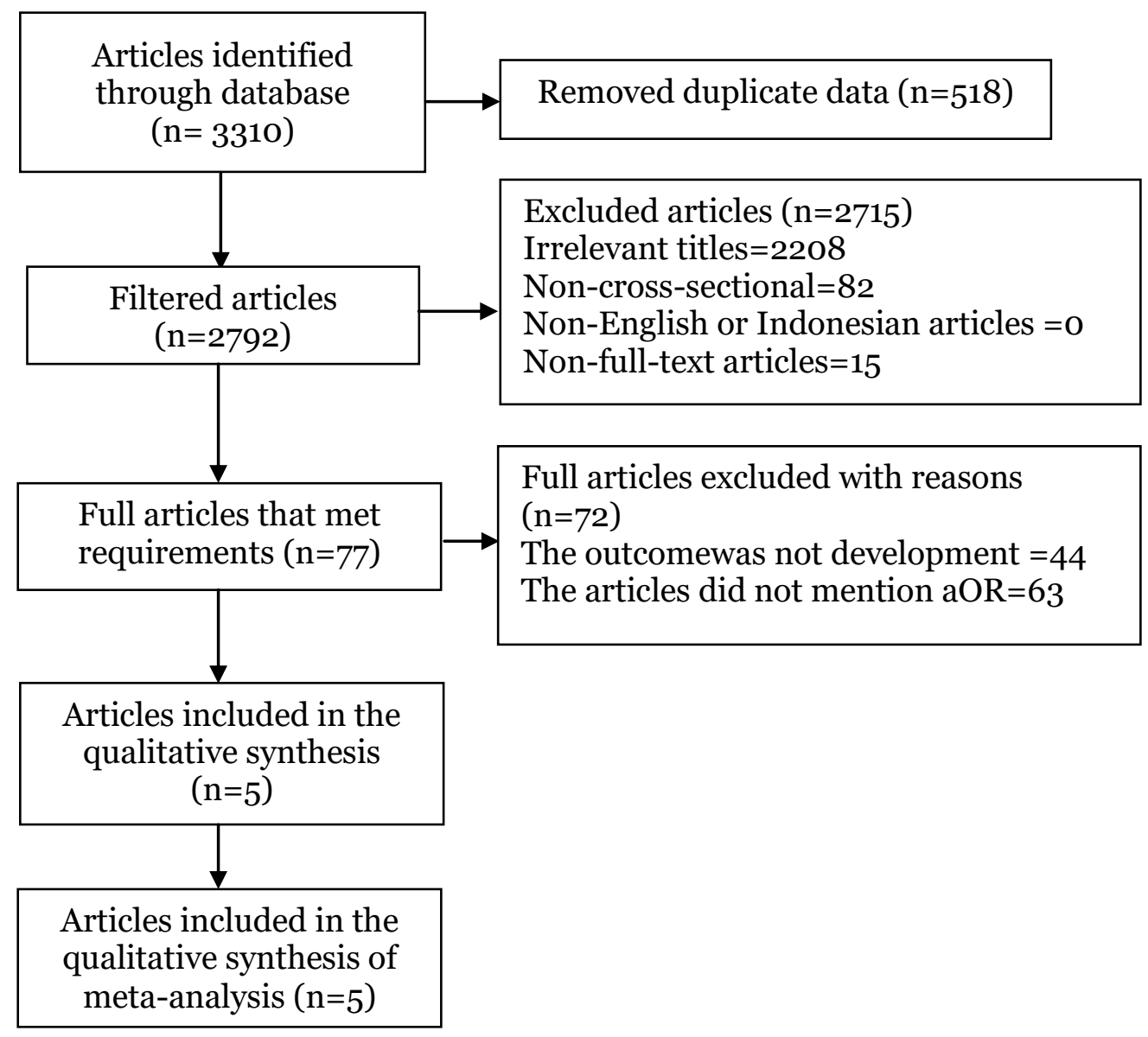

Figure 1 Flow chart of the review process 
1. Summary Source

There are 5 observational study articles as a source of a meta-analysis of the effect of stunting on child development.

Table 1. Primary study descriptions were included in the meta-analysis

\begin{tabular}{|c|c|c|c|c|c|c|c|}
\hline $\begin{array}{l}\text { Author } \\
\text { (year) }\end{array}$ & Country & $\begin{array}{l}\text { Design } \\
\text { of the } \\
\text { study }\end{array}$ & $\mathbf{S}$ & $\mathbf{P}$ & $\mathbf{I}$ & $\mathbf{C}$ & $\mathbf{O}$ \\
\hline $\begin{array}{l}\text { Probosiwi } \\
\text { et al. (2017) }\end{array}$ & Indonesia & $\begin{array}{l}\text { Cross- } \\
\text { sectional }\end{array}$ & 106 & $\begin{array}{l}\text { Children } \\
\text { aged 12-60 } \\
\text { months }\end{array}$ & $\begin{array}{l}\text { Stunted boys and girls who } \\
\text { visited the integrated health post, } \\
\text { no abnormalities, no congenital } \\
\text { infections, and no congenital } \\
\text { malformation }\end{array}$ & $\begin{array}{l}\text { Non-stunted children, male and } \\
\text { female, visited integrated health } \\
\text { post, no abnormalities, no congenital } \\
\text { infections, and no congenital } \\
\text { malformation }\end{array}$ & $\begin{array}{l}\text { Child } \\
\text { Development }\end{array}$ \\
\hline $\begin{array}{l}\text { Hizni et al. } \\
(2010)\end{array}$ & Indonesia & $\begin{array}{l}\text { Cross- } \\
\text { sectional }\end{array}$ & 166 & $\begin{array}{l}\text { Children } \\
\text { aged } 12-60 \\
\text { months }\end{array}$ & $\begin{array}{l}\text { Stunted children raised by birth } \\
\text { mother, no chronic diseases, no } \\
\text { congenital malformation, no } \\
\text { history of difficult labor }\end{array}$ & $\begin{array}{l}\text { Non-stunted children raised by birth } \\
\text { mother, no chronic diseases, no } \\
\text { congenital malformation, no history } \\
\text { of difficult labor }\end{array}$ & $\begin{array}{l}\text { Child } \\
\text { Development }\end{array}$ \\
\hline $\begin{array}{l}\text { Syahrani } \\
\text { dan Mitra } \\
\text { (2019) }\end{array}$ & Indonesia & $\begin{array}{l}\text { Cross- } \\
\text { sectional }\end{array}$ & 220 & $\begin{array}{l}\text { Children } \\
\text { aged 3-5 } \\
\text { years }\end{array}$ & $\begin{array}{l}\text { Stunted children who lived with } \\
\text { their parents, no chronic diseases, } \\
\text { no congenital malformation }\end{array}$ & $\begin{array}{l}\text { Non-stunted children who lived with } \\
\text { their parents, no chronic diseases, } \\
\text { no congenital malformation }\end{array}$ & $\begin{array}{l}\text { Child } \\
\text { Development }\end{array}$ \\
\hline $\begin{array}{l}\text { Permatasari } \\
\text { (2013) }\end{array}$ & Indonesia & $\begin{array}{l}\text { Cross- } \\
\text { sectional }\end{array}$ & 60 & $\begin{array}{l}\text { Children } \\
\text { aged2 years }\end{array}$ & $\begin{array}{l}\text { Children visited integrated health } \\
\text { post, no congenital malformation, } \\
\text { no LBW and premature history, } \\
\text { no history of difficult labor }\end{array}$ & $\begin{array}{l}\text { Children visited integrated health } \\
\text { post, no congenital malformation, no } \\
\text { LBW and premature history, no } \\
\text { history of difficult labor }\end{array}$ & $\begin{array}{l}\text { Child } \\
\text { Development }\end{array}$ \\
\hline $\begin{array}{l}\text { Amaliah et } \\
\text { al. (2016) }\end{array}$ & Indonesia & $\begin{array}{l}\text { Cross- } \\
\text { sectional }\end{array}$ & 95 & $\begin{array}{l}\text { Children } \\
\text { aged 6-23 } \\
\text { months }\end{array}$ & $\begin{array}{l}\text { Stunted children who visited } \\
\text { integrated health post, had MCH } \\
\text { book }\end{array}$ & $\begin{array}{l}\text { Non-stunted children who visited } \\
\text { integrated health post, had MCH } \\
\text { book }\end{array}$ & $\begin{array}{l}\text { Child } \\
\text { Development }\end{array}$ \\
\hline
\end{tabular}

*Variables included in a meta-analysis study 
Rosyidah et al./ Effects of Stunting on Child Development

3310 articles were found at the beginning of the search process. 2792 articles were found after eliminating the duplicate articles. 77 articles met the criteria for further full-text review. The articles that met the qualitative criteria were re-reviewed. In the end, 5 articles met the quantitative criteria for a meta-analysis of the effect of stunting on child development.

\section{Forest plot}

\section{Odds Ratio Odds Ratio}

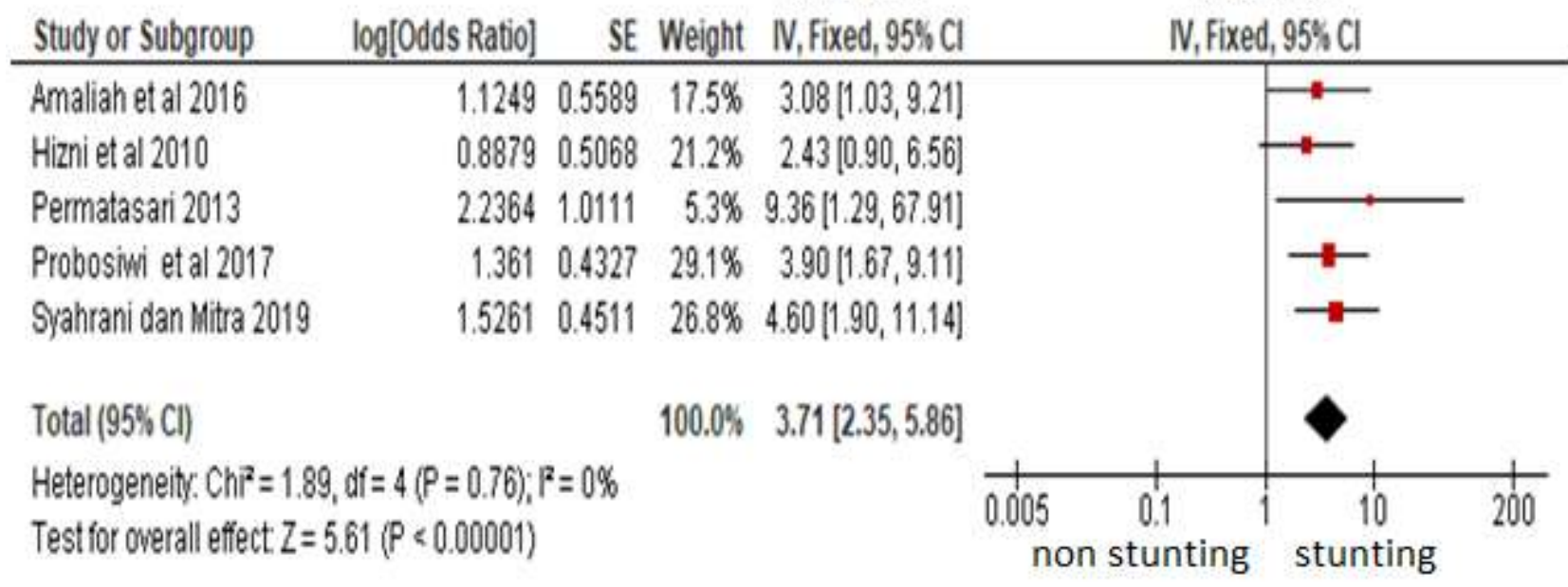

Figure 2. Forest plot of the effects of stunting on child development

\section{Funnel plot}

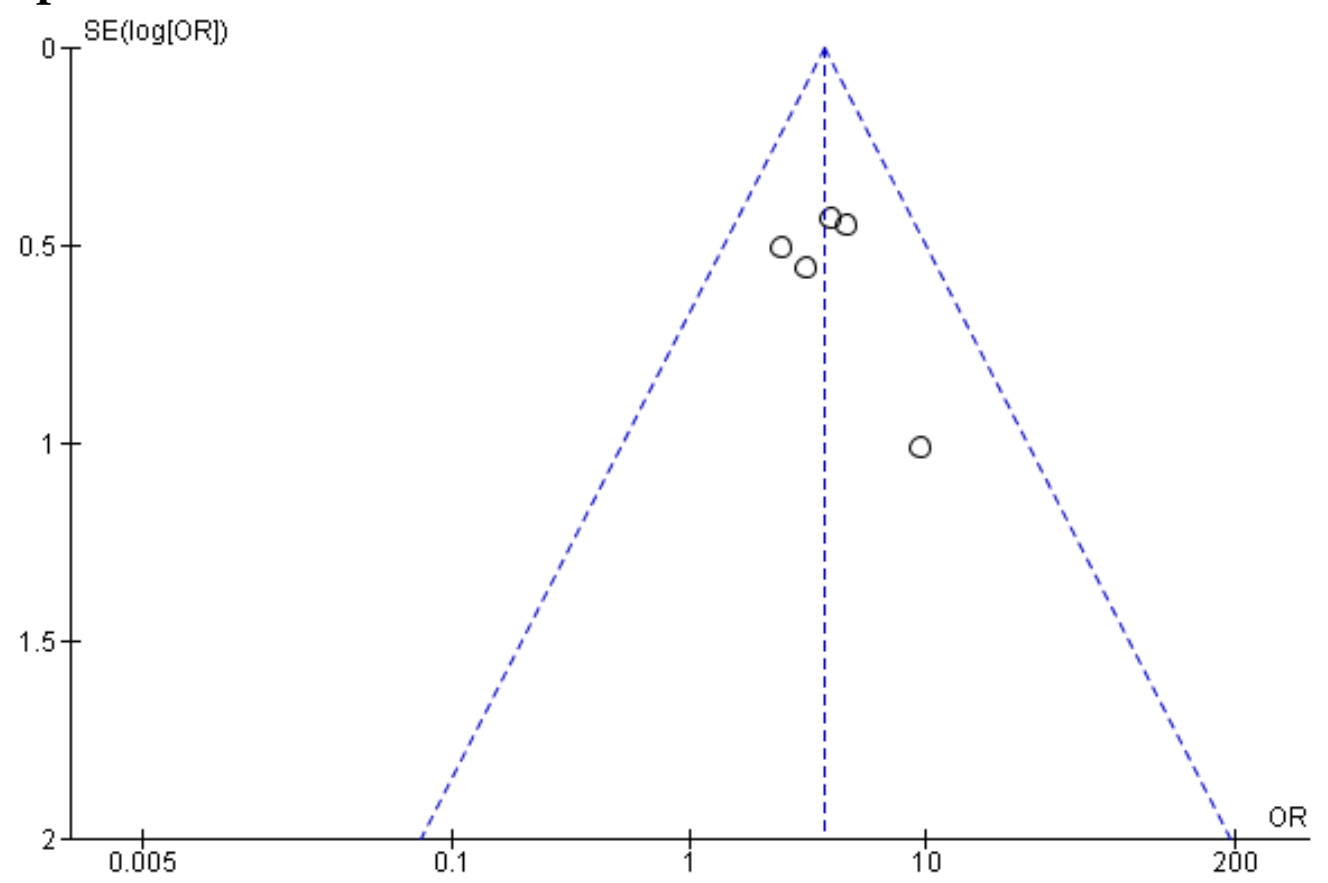

Figure 3. Funnel plotof the effects of stunting on child development 
The interpretation of the results of the metaanalysis showed that stunting increased poor development by 3.71 times compared to nonstunted children. It was statistically significant $(p=0.760)$. The heterogeneity of the data showed $\mathrm{I}^{2}=0 \%$. Therefore, the distribution of the data was homogeneous (fixedeffect model). Based on Figure 3, there was a publication bias characterized by the asymmetry of the right and left plots, where 3 plots were on the right and 2 plots were on the left. The plot on the left of the graph had a standard error between 0.5 and 1 and the plot on the right had a standard error between $o$ and 1.5. Bias also occurred from an imbalance between the distance among the studies on the right and left of the funnel plot.

\section{DISCUSSION}

This study was a systematic study and a meta-analysis. This study aimed to obtain conclusions from the results of similar studies regarding the effect of stunting on child development. A study that discusses data on stunting with progression was considered important because there were issues of inconsistency/controversy with the results of various studies/primary studies that have been carried out. The number of relevant studies published and accessible was still few and also had data access problems (data duplication) (Murti, 2018). Most of the statistical results reported were in the form of a percentage or a crude odd ratio (cOR), where most studies did not control for confounding factors.

The confounding factor that affected the relationship or effect of exposure on the occurrence of disease estimated by the study was not the same as the relationship or effect that occurs in the target population, which means the study results were invalid (Murti, 2018). This systematic study and a metaanalysis used a study that controlled for con- founding factors coming from the inclusion criteria namely multivariate analysis. The statistical result reported was the adjusted odd ratio (aOR).

The estimation of the combined effect of stunting on development was processed using the RevMan 5.3 application with the generic inverse variance method. This method aimed to analyze data in the form of rate, time-to-event, hazard ratio, ordinal scale, adjusted estimate, difference of mean, or ratio of mean.

The results of the systematic study and a meta-analysis were presented in the form of a forest plot and a funnel plot. The forest plot described an overview of the information from each of the studies examined in the meta-analysis and estimation of the overall results (Murti, 2018). The forest plot showed visually the amount of variation (heterogeneity) in study results (Akobeng in Murti, 2018).

The funnel plot was a diagram in a meta-analysis used to demonstrate possible publication bias. The funnel plot showed the relationship between the effect size of the study and the sample size or standard error of the effect size of the various studies examined (Murti, 2018).

The funnel plot shows visually the amount of variation (heterogeneity) (Akobeng, 2005 in Murti, 2018). The funnel plot showed the relationship between the effect size of the study and the sample size of the various studies examined. It could be measured in many different ways (Murti, 2018).

\section{Stunting dan development}

The results of a meta-analysis of 6 articles regarding the effect of stunting on child development are summarized in a forest plot. The forest plot in Figure 2 shows that children who were stunted were 3.71 times more likely to have abnormal development than children who were not stunted. This result was statis- 
tically significant $(\mathrm{aOR}=3.71 ; 95 \% \mathrm{CI}=2.35$ to 5.86; $\mathrm{p}=0.760$ ).

This is in line with a study by Hairunis et al., (2018) that children under five with normal stature had a 3.3 times possibility of having appropriate development compared to stunted children under five. In children under five, the aspect of growth and development is one of the aspects that are taken seriously because it explains the process of forming a person, both physically and psychosocially. The part of child development consisted of gross motor skills, fine motor skills, language and speech, and social/ personal independence (Hairunis et al., 2018).

Based on another study conducted by Casale et al., 2014, stunting affected children's motor development. This study aimed to contribute to the impact of undernutrition in children by exploring the relationship between stunting in early childhood and measuring child development using longitudinal data from a cohort study of children born in Johannesburg, South Africa. This study observed confounding factors that control socio-economic status, various special characteristics of children, home environment, and nanny's suggestions. The results of the multivariate analysis showed that stunted children aged 2 years did much worse on measures that captured fine motor skills and cognitive function (Casale et al, 2014).

Another study conducted by Amaranggani et al. in 2018 stated that stunting was related to children's social-emotional development. Children who were stunted might lose curiosity about the environment. Less optimal development of intelligence affected the disruption of children's emotional intelligence and the loss of children's curiosity about the environment, thus inhibiting the process of children's social development (Amaranggani et al., 2018).
Another study conducted by Kang et al. (2018) stated that stunting was related to child development. Children who were stunted had a greater risk of having suboptimal development than children with appropriate height for their age. Intervention that increases linear growth and decreases stunting could have a positive effect on developmental outcomes in infancy and early childhood. The integration of nutrition interventions and strategies to increase stimulation and early learning tended to have a synergistic positive effect on early childhood development and should be an investment priority in the South Asia Region (Kang et al., 2018).

This meta-analysis concluded that children who were stunted had 3.71 times the risk of having abnormal development compared to children who were not stunted $(\mathrm{aOR}=$ $3.71 ; 95 \% \mathrm{CI}=2.35$ to $5.86 ; \mathrm{p}=0.760$ ). This meta-analysis combined 5 primary studies using a cross-sectional design from Indonesia (Sleman Yogyakarta, Cirebon, West Java, Indragiri Hilir Riau Regency, Karanganyar Regency, Central Java, and Bekasi City, West Java).

\section{AUTHOR CONTRIBUTION}

Rosyidah Milatur was the main researcher who selected the topic, examined, and collected the data. Yulia Lanti Retno Dewi and Isna Qadrijati played a role in analyzing the data and reviewing the documents.

\section{CONFLICT OF INTEREST}

This study did not have any conflict of interest.

\section{FUNDING AND SPONSORSHIP}

This study used personal funds from the main researcher. 


\section{ACKNOWLEDGEMENT}

We would like to thank the database provider of PubMed, ScienceDirect, dan Google Scholar.

\section{REFERENCE}

Amaranggani PPA, Sabar S, Nur D (2018). Hubungan stunting dengan perkembangan sosial emosional anak pra sekolah di wilayah kerja puskesmas kalasan kabupaten sleman. Skripsi, Poltekkes Kemenkes Yogyakarta.

Amaliah N, Sari K, Suryaputri IY (2016). Panjang badan lahir pendek sebagai salah satu faktor determinan keterlambatan tumbuh kembangan anak umur 6-23 bulan di Kelurahan Jaticempaka Kecamatan Pondok Gede Kota Bekasi. Jurnal Ekologi Kesehatan. 15 (1): 4355. http://dx.doi.org/10.22435/jek.v15i1.4959.43-55.

Amir NAR, Budihastuti UR, Murti B (2019). Factors associated with development in children under five. J Matern Child Health. 4(1): 40-48. https://doi.org/10.26911/thejmch.2019.04.01.06.

Andriana D (2013). Tumbuh kembang dan terapi bermain pada anak. Jakarta: Salemba Medika

Ardian R (2016). Hubungan stunting dan gizi kurang dengan skor IQ anak sekolah dasar umur 8 tahun di kecamatan bululawang kabuapaten malang. Tesis, Uiversitas Sebelas Maret Surakarta.

Armini NW, Sriasih NGK, Marhaeni GA. (2017). Asuhan kebidanan neonatus, bayi, balita, dan anak prasekolah. Yogyakarta: Penerbit ANDI.

Butchon R, Liabsuetrakul T (2017). The development and growth of children aged under 5 years in Northeastern Thailand: a cross sectional study. J Child Adolesc Behav. 5(1): 334. doi:10.4172/2375-4494.1000334.
Casale D, Desmond C, Richter L (2014). The association between stunting and psychosocial development among preschool children: a study using the south african birth to twenty cohort data. Child Care Health Dev. 40 (6): 900910. doi:10.1111/cch.12143.

Cheung MWL (2015). Meta analysis a structural equation modeling approach. Singapore: John Wiley \& Sons, Ltd.

Dahlan MS (2012). Langkah-langkah membuat proposal penelitian bidang kedokteran dan kesehatan. Jakarta: Sagung Seto.

Dewi AR, Dewi YLR, Murti B (2019). Life course factors associated with stunting in children aged 2-5 years: a path analysis. Matern Child Health J. 4 (5): 358367. https://doi.org/10.26911/thejmch.2019.04.05.09.

Dinkes Banyuwangi. (2020). Data seputar kesehatan. Banyuwangi: Dinas Kesehatan Banyuwangi.

Gunasari DSA (2016). Hubungan stunting dengan tingkat kecerdasan intelektual (Intelligence Quotient- IQ) pada anak baru masuk sekolah dasar di kecamatan nanggalo kota padang. Skripsi, Universitas Andalas Padang.

Hairunis MN, Salimo H, Dewi YLR (2018). Hubungan status gizi dan stimulasi tumbuh kembang dengan perkembangan balita. Sari Pediatri. 20(3):146151. https://dx.doi.org/10.14238/sp20.3.2018.146-51.

Hizni A, Julia M, Gamayanti IL (2010). Status stunted dan hubungannya dengan perkembangan anak balita di wilayah pesisir pantai utara Kecamatan Lemahwungkuk Kota Cirebon. Jurnal Gizi Klinik Indonesia. 6(3): 131-137. https://doi.org/10.22146/ijcn.17721.

Human Development Worker (2018). Buku saku kader pembangunan manusia (KPM) memastikan konvergensi pena- 
nganan stunting desa. Jakarta: Kementerian Desa Pembangunan Daerah Tertinggal dan Transmigrasi.

Kang Y, Aguayo VM, Campbell RK, West KP (2018). Association between stunting and early childhood development among children aged 36-59 months in south asia. Matern Child Nutr. 14(4):111. https://doi.org/10.1111/mcn.12684.

Kementerian Desa Pembangunan Daerah Tertinggal dan Transmigrasi (2017). Buku saku desa dalam penanganan stunting. Jakarta: Kementerian Desa Pembangunan Daerah Tertinggal dan Transmigrasi.

Kemenkes (2015). Situasi kesehatan anak balita di indonesia. Jakarta: Pusat Data dan Informasi Kementerian Kesehatan RI.

Kemenkes RI (2018). Situasi balita pendek (stunting) di indonesia. Jakarta: Pusat Data dan Informasi

KOMINFO (2019). Bersama perangi stunting. Jakarta: TIMIndonesiabaik.id.

Kusuma EK, Nuryanto N (2013). Faktor risiko kejadian stunting pada anak usia 2-3 tahun. Journal of Nutrition College. 2(4): 523-530. https://doi.org/10.14710/jnc.v2i4.3735.

Maharani SDS, Wulandari SR, Melina F. (2018). Hubungan antara kejadian stunting dengan perkembangan pada balita usia 3-5 tahun di posyandu Kricak Yogyakarta. Jurnal Ilmiah Kesehatan. 7(1): 37-46. https://ejournal.umpri.ac.id/index.php/JIK/article/view/1095.

Maternity D, Anjani AD, Evrianasari N. (2018). Asuhan kebidanan neonatus, bayi, balita dan anak prasekolah. Yogyakarta: ANDI.

Muhoozi GK, Atukunda P, Mwadime R, Iversen PO, Westerberg AC (2016). Nutritional and developmental status among 6-to 8-monthold children in
Southwestern Uganda: a cross sectional study. Food Nutr Res. 1(60):30270, DOI: $10.3402 /$ fnr.v60.30270.

Murti B. (2018). Prinsip dan metode riset epidemologi edisi ke empat. Surakarta: Universitas Sebelas Maret.

Ningrum EW, Utami T (2018). Stunting status and developmnt of children under 5 year old in Padamara community health service centre in Indonesia. Jurnal Keperawatan Soedirman. 13(1): 27-31. http://dx.doi.org/10.20884/1.jks.2018.13.1.786.

Nurmalasari Y, Yudhasena N, Utami D (2019). Hubungan stunting dengan perkembangan motorik kasar pada balita usia 6-59 bulan di desa mataram Ilir kec. seputih surabaya kabupaten lampung tengah. Jurnal Ilmu Kedokteran dan Kesehatan. 6(4): 264-273. https://doi.org/10.33024/jikk.v6i2.2122.

Pantaleon MG, Hadi H, Gamayanti IL (2015). Stunting berhubungan dengan perkembangan motorik anak di kecamatan Sedayu, Bantul, Yogyakarta. Jurnal Gizi dan Dietetik Indonesia (Indones J Nutr Dietetic). 3(1): 10-21. http://dx.doi.org/10.21927/ijnd.2015.3(1).10-21.

Pem D (2012). Factors affecting early childhood growth and development: golden 1000 days. Adv Practice Nurs. 1(1):101. doi: 10.4172/2573-0347.1000101.

Pemkab Banyuwangi. (2019). Data seputar kesehatan. Banyuwangi: Pemerintah Kabupaten Banyuwangi.

Perkins JM, Kim R, Krishna A, McGovern M, Aguayo VM, Subramanian SV (2017). Understanding the association between stunting and child development in lowand middle-income countries: next steps for research and intervention. Soc. Sci Med. 1(193):101-109. DOI 10.1016/j.socscimed.2017.09.039. 
Permatasari (2013). Hubungan antara status gizi dengan perkembangan anak usia 1000 hari pertama kehidupan. Skripsi, Universitas Sebelas Maret Surakarta.

Probosiwi H, Huriyati E, Ismail D (2017). Stunting dan perkembangan anak usia 12-60 bulan di Kalasan. Berita Kedokteran Masyarakat. 33(11): 11411146. https://doi.org/10.22146/bkm.26550.

Rivanica R, Oxyandi M (2016). Buku ajar deteksi dini tumbuh kembang dan pemeriksaan bayi baru lahir. Jakarta: Salemba Medika.

Sekretariat Wakil Presiden Republik Indonesia (2017). 10o kabupaten / kota prioritas untuk intervensi anak kerdil (stunting). Jakarta: Tim Nasional Percepatan Penanggulangan Kemiskinan.

Setiawan B (2018). Faktor-faktor penyebab stunting pada anak usia dini. Bekasi: Yayasan Rumah Komunitas Kreatif.

Shinkfeld A (2017). Working in early childhood book 1 learner's workbook revised version 2017. Australia: Goverment Of Western Australia.

Singh R, Bisht N, Parveen H (2019). Principles, milestones and interventions for early years of human growth and development: an insight. Int J Curr Microbiol Appl Sci. 8(6): 181-190 https://doi.org/10.20546/ijcmas.2019.806.022

Sukoco NEW, Pambudi J, Herawati MH (2015). Relationship between nutritional status of children under five with parents who work. Buletin Penelitian Sistem Kesehatan. 18(4): 387-397.

Sulistyawati A (2014). Deteksi tumbuh kembang anak. Jakarta: Salemba Medika.

Syahrani, Mitra (2019). Hubungan stunting dengan perkembangan anak usia (3-5 tahun) di wilayah kerja puskesmas Sungai Piring Kabupaten Indragiri Hilir. Excellent Midwifery Journal. 2(2): 108-115. http://jurnal.mitrahusada.ac.id/index.php/emj/article/view/98.

Trihono, Atamarita, Tjandrarini DH, Irawati A, Utami NH, Tejayanti T, Nurlinawati I. (2015). Pendek (stunting) di indonesia, masalah dan solusinya. Jakarta: Lembaga Penerbit Balitbangkes.

Wahyuni N, Lamri, Siregar N (2019). Hubungan status gizi stunting dengan perkembangan balita usia 2-5 tahun di wilayah kerja puskesmas mangkupalas samarinda. Skripsi, Poltekkes Kalimantan Timur.

WHO. (2018). Reducing stunting in children: equity considerations for achieving the global nutrition targets 2025. Geneva.

Wulandari UR, Budhiastuti UR, Pamungkasari EP (2017). Analysis of life-course factors influencing growth and development in children under 3 years old of early marriage women in Kediri. Matern Child Health J. 2(2): 137-149 https://doi.org/10.26911/thejmch.2017.02.02.05. 